\title{
Productivity and body composition of Black-headed Mutton sheep x Polish Merino crossbred rams fed complete pelleted mixtures with different energy concentrations
}

\author{
M. Urbaniak, A. Potkański, A. Frankiewicz, I. Przybecka \\ and J. Matyniak
}

\author{
Department of Animal Nutrition and Feed Management. \\ August Cieszkowski Agriculture University \\ Wotynska 33, 60-637 Poznan, Poland
}

(Received 19 April 2000; accepted 4 October 2000)

\section{ABSTRACT}

Thirty-two Black-headed Mutton sheep x Polish Merino crossbred lambs weighing about $22 \mathrm{~kg}$ were divided into two groups and fed two isonitrogenous complete pelleted diets containing low (group L) or high (group $\mathrm{H}$ ) metabolisable energy (ME) levels. The animals were fattened to a final liveweight of about $36 \mathrm{~kg}$. Average daily gains in groups $\mathrm{L}$ and $\mathrm{H}$ were 228 and $250 \mathrm{~g}$; intake per $\mathrm{kg}$ gain was: ME, 56.6 and $54.8 \mathrm{MJ}$; crude protein, 718 and $649 \mathrm{~g}$, respectively. Mean daily clean wool fibre production was similar in both groups ( $3.66 \mathrm{vs} 3.75 \mathrm{~g}$ ). The concentration of ME in diets did not significantly influence dressing percentage or morphological composition of the carcass. The protein content in $1 \mathrm{~kg}$ of empty body weight (EBW) ranged from 18.6 to $18.8 \%$, fat from 17.6 to $18.1 \%$, while energy value from 11.25 to $11.55 \mathrm{MJ}$ in groups $\mathrm{L}$ and $\mathrm{H}$, respectively. The utilisation of $\mathrm{ME}$ available for growth $\left(\mathrm{k}_{\mathrm{r}}\right)$ by lambs from groups $\mathrm{L}$ and $\mathrm{H}$ was similar $(0.38 \mathrm{vs} 0.40)$. Animals from group $H$ deposited a little more protein in EBW gain $(39.1 \mathrm{~g} / \mathrm{d})$ than lambs from group $\mathrm{L}(36.8 \mathrm{~g} / \mathrm{d})$.

KEY WORDS: lambs, energy level, protein deposition, energy deposition

\section{INTRODUCTION}

So far Polish sheep breeders have failed to develop local domestic meat type sheep breeds and, on the other hand, natural conditions prevailing in our country place specific constraints on rearing and utilisation of imported valuable meat type 
shecp brecds (Suffolk, Berrichonne du Cher. Texel) which come, primarily, from sca climates.

For the above reasons, investigations were undertaken at A. Cieszkowski Poznań Agricultural University with the aim to develop domestic meat sheep breeds. So far, researchers succeeded in breeding four new synthetic lines of meat sheep for which separate flock books have been established. One of the registered synthetic lines is a Black-headed Mutton sheep which was obtained as the result of crossing Suffolk, Wiclkopolska, Polish Merino and East-Friesian sheep (Gut and Slósarz, 1995). Currently, breeding material of this line is being distributed all over the country for commercial crossing, mainly with cwes of the Polish Merino breed.

In view of the above arguments, it was justifiable, for both cognitive and practical reasons, to undertake nutritional studies concerning estimation of chemical body composition and deposition of protein and encrgy by crossbreed sheep derived from the above synthetic line.

The aim of this research was to determine the productivity, chemical composition of empty body weight (EBW) and protein and energy deposition in Blackheaded Mutton sheep x Polish Merino crossbred lambs, fed complete pelleted diets of two different levels of metabolisable energy (ME).

\section{MATERIAL AND METHODS}

Thirty-two Black-headed Mutton sheep x Polish Merino crossbred rams weighing an avcrage of $22 \mathrm{~kg}$ were randomly allocated to two groups (16 animals in each) and fed two isonitrogenous (approximately $15 \%$ crude protein $/ \mathrm{kg}$ dry matter) complete pelleted dicts containing 11.97 (group L) or 12.86 (group H) MJ $\mathrm{ME} / \mathrm{kg}$ dry matter. The components of the diets are listed in Table 1, while their chemical composition and energetic value are given in Table 2 . The dictary ME contents were calculated on the basis of our own results of chemical analysis using equation $N^{\circ} 75$ given by ARC (1984):

$$
\mathrm{MJ} \mathrm{ME} / \mathrm{kg} \mathrm{DM}=0.012 \mathrm{x}_{1}+0.031 \mathrm{x}_{2}+0.005 \mathrm{x}_{3}+0.014 \mathrm{x}_{4}
$$

in which $x_{1} x_{2}, x_{3}$ and $x_{4}$ designate dictary content ( $\mathrm{g} / \mathrm{kg}$ dry matter) of crude protein, ether extract, crude fibre and $\mathrm{N}$-frec extractives, respectively.

Before the beginning of the experiment, 4 additional lambs (zero group) wcighing $22 \mathrm{~kg}$ were selected. sheared and slaughtered to determine the amount of fleece and chemical composition of their body. The experimental animals werc penned individually and fed one of two rations in the amount of $1150 \mathrm{~g} / \mathrm{head} / \mathrm{d}$ (liveweight of animals $20.0-28.0 \mathrm{~kg}$ ) and later $1380 \mathrm{~g} / \mathrm{head} / \mathrm{d}$ (liveweight of animals $28.1-36.0 \mathrm{~kg}$ ). The rations were split into equal parts that were fed at 7.00 and $14.00 \mathrm{~h}$. During fattening liveweight and feed intake were recorded. 
TABLE 1

Composition of complete pelleted mixtures, \%

\begin{tabular}{lcc}
\hline & \multicolumn{2}{c}{ Group } \\
\cline { 2 - 3 } & $\mathrm{L}$ & $\mathrm{H}$ \\
\hline Dehydrated fucerne & 12.29 & 9.87 \\
Soyabean meal & 5.70 & 7.80 \\
Barley & 48.53 & 15.17 \\
Wheat & 11.47 & 47.50 \\
Wheat brans & 19.90 & 5.00 \\
Potatoe starch & - & 12.75 \\
Limestone & 1.61 & 1.41 \\
Minerat - vitamin premix & 0.50 & 0.50 \\
\hline
\end{tabular}

contains in $1 \mathrm{~kg}: 1600000 \mathrm{IU}$ vit. A, $130000 \mathrm{IU}$ vit. $\mathrm{D}_{3}, 2000 \mathrm{mg}$ vit. E, $500 \mathrm{mg}$ vit. $\mathrm{B}_{1}, 2000 \mathrm{mg}$ $\mathrm{Fe}, 1600 \mathrm{mg} \mathrm{Cu}, 8000 \mathrm{mg} \mathrm{Mn}, 9000 \mathrm{mg} \mathrm{Zn}, 80 \mathrm{mg} \mathrm{I}, 20 \mathrm{mg}$ Co, $30 \mathrm{mg} \mathrm{Se}, 40 \mathrm{mg} \mathrm{Mg}$

TABLE 2

Chemical composition ( $\mathrm{g} / \mathrm{kg}$ dry matter) and energetic value of complete pelleted mixtures

\begin{tabular}{lcc}
\hline & \multicolumn{2}{c}{ Group } \\
\cline { 2 - 3 } & \multicolumn{1}{c}{$\mathrm{L}$} & $\mathrm{H}$ \\
\hline Dry matter $^{3}$ & 868 & 871 \\
Crude protein $^{-1}$ & $15 !$ & 150 \\
Ether extract & 26 & 20 \\
N-free extractives & 618 & 727 \\
Crude fibre & 138 & 53 \\
Crude ash & 67 & 50 \\
Ncid detergent fibre & 114 & 108 \\
Neutral detergent fibre & 220 & 211 \\
& & \\
Metabolisable energy (ME) & 11.97 & 12.86 \\
MJ/kg DM & & \\
\hline
\end{tabular}

" air-basis dry matter

The trial was terminated when the lambs reached a weight of about $36 \mathrm{~kg}$. Then they were sheared, starved for $20 \mathrm{~h}$ and slaughtered. Flecce yicld was determined by shearing and samples of fleece from the shoulder, flank and thigh were collected. These samples were used to determine the yield of clean wool fibre according to the method described by Urbaniak (1986). Animals from the zero group were treated similarly. The EBW of lambs was expressed as the sum of all slaughter products (including blood) less the content of the digestive tract, gallbladder and 
bladder. The samples from each animal were autoclaved, freeze-dricd and then their chemical composition and energy content were determined. Energy in wool was calculated from its chemical composition by multiplying the quantity of protein and fat contents by the energy value coefficients given by Urbaniak and Potkański (1987) which equal $5.609 \mathrm{kcal} / \mathrm{g}$ and $9.741 \mathrm{kcal} / \mathrm{g}$, respectively. Energy and protein retention in lamb bodies (including wool) were calculated from the difference between the content of these components in the animal body at the beginning and end of the experiment.

The basic chemical composition of fecds, wool and lyophilizates of slaughter products was determined using standard methods. ADF and NDF were determined by the method of Goering and Van Soest (1970). An automatic calorimeter was used to determine the energy content in lyophilizates.

To compare treatment means the analysis of variance (Steel and Torric, 1960) and the Duncan s multiple range test were used.

\section{RESULTS}

Liveweight gains. wool production and feed utilisation in lamb fattening are presented in Table 3 . The highest average liveweight gains were recorded in lambs fed diets containing $12.86 \mathrm{MJ} \mathrm{ME}$ (group $\mathrm{H}$ ), $250 / \mathrm{d}$, while the rams from group $\mathrm{L}$ grew significantly more slowly $(\mathrm{P} \leq 0.05), 228 \mathrm{~g} / \mathrm{d}$. Animals from group $\mathrm{H}$ used significantly $(\mathrm{P}<0.05)$ less crude protein per unit of liveweight gain.

TABLE 3

Liveweight gains, feed utilisation and wool production in fattening lambs

\begin{tabular}{lccc}
\hline & \multicolumn{2}{c}{ Group } & SE \\
\cline { 2 - 3 } & $\mathrm{L}$ & $\mathrm{H}$ & \\
\hline Initial weight, $\mathrm{kg}$ & 21.5 & 22.0 & 1.6 \\
Final weight, $\mathrm{kg}$ & 35.4 & 36.0 & 2.6 \\
Duration, days & $6 !$ & 56 & 3.7 \\
Liveweight gain, g/day & $228^{\circ}$ & $250^{\mathrm{i}}$ & 12 \\
Feed utilisation: & & & \\
$\quad$ crude protcin, g/kg gain & $718^{\circ}$ & $649^{\mathrm{il}}$ & 46 \\
$\quad$ ME, MJ/kg gain & 56.6 & 54.8 & 3.8 \\
Wool production', g/day & 3.66 & 3.75 & 0.18 \\
\hline
\end{tabular}

standard error of the mean

b clean wool fibre

$\therefore \mathrm{d}$ means in the same row bearing different superscripts differ $\mathrm{P}=0.05$ 
Clean wool fibre production did not differ significantly between groups, but the little higher value of this parameter $(3.75 \mathrm{vs} 3.66 \mathrm{~g} / \mathrm{d})$ was found in lambs from group $\mathrm{H}$. The level of dietary cnergy did not have a significant influence on dressing percentage and morphological composition of the carcass (Table 4).

TABLE 4

Dressing percentage and carcass composition

\begin{tabular}{|c|c|c|c|}
\hline & \multicolumn{2}{|c|}{ Group } & \multirow{2}{*}{$\mathrm{SE}^{\mathrm{a}}$} \\
\hline & $\mathrm{L}$ & $\mathrm{H}$ & \\
\hline Dressing percentage, $\%$ & 48.7 & 49.1 & 2.8 \\
\hline \multicolumn{4}{|l|}{ Carcass composition. $\%$} \\
\hline lean & 59.2 & 59.4 & 3.0 \\
\hline fat & 16.3 & 16.1 & 1.0 \\
\hline bone & 20.3 & 20.6 & 1.6 \\
\hline connective tissue & 4.2 & 3,9 & 0.2 \\
\hline
\end{tabular}

standard error of the mean

The energy concentration in diets did not have a significant influence on chemical composition and energetic valuc of EBW (Table 5). Protein content in $1 \mathrm{~kg}$ EBW ranged from 18.59 to $18.82 \%$, fat from 17.60 to $18.10 \%$, while energetic valuc from 11.25 to $11.55 \mathrm{MJ}$.

The amount of energy deposited in the lambs' bodies (Tables 6) was similar in both groups. However, the coefficient of utilisation of ME available for growth $\left(\mathrm{k}_{\mathrm{f}}\right)$ was found to be a little higher in lambs from group $\mathrm{H}$, but differences between groups were not significant $(\mathrm{P}>0.05)$.

The energy concentration in the diets did not significantly influence $(\mathrm{P} \geq 0.05)$ protein deposition in lambs' bodics (Table 7). The largest quantities of protein were retained by lambs from group $\mathrm{H}, 36.1 \mathrm{~g} / \mathrm{d}$ in EBW gain, $3.0 \mathrm{~g} / \mathrm{d}$ in wool gain

TABLE 5

Chemical composition and energetic value of $1 \mathrm{~kg}$ EBW (wool included) of lambs

\begin{tabular}{|c|c|c|c|}
\hline & \multicolumn{2}{|c|}{ Group } & \multirow{2}{*}{$\mathrm{SE}^{\circ}$} \\
\hline & $\mathrm{L}$ & $\mathrm{H}$ & \\
\hline Dry matter . $\%$ & 40.30 & 40.92 & 2.82 \\
\hline Crude protein. $\%$ & 18.59 & 18.82 & 1.11 \\
\hline Ether extract, \% & 17.60 & 18.10 & 1.23 \\
\hline Crude ash, $\%$ & 4.11 & 4.00 & 0.20 \\
\hline Gross energy. MJ & 11.25 & 11.55 & 0.86 \\
\hline
\end{tabular}

" standard error of the mean 
TABLE 6

Metabolisable encrgy utilisation by lambs

\begin{tabular}{|c|c|c|c|}
\hline & \multicolumn{2}{|c|}{ Group } & \multirow{2}{*}{$S E^{i \prime}$} \\
\hline & $\mathbf{L}$ & $\mathrm{H}$ & \\
\hline Total ME intake. MJ/ lambs & 788 & 760 & 54 \\
\hline Maintenance reguirement ${ }^{b}, \mathrm{MJ}$ & 183 & 168 & 9 \\
\hline ME available for growth. $\mathrm{MJ}$ & 605 & 600 & 40 \\
\hline Energy deposition " MJ & 229 & 240 & 12 \\
\hline ME utilisation, $\mathrm{k}_{\mathrm{f}}$ & 0.38 & 0.40 & 0.02 \\
\hline
\end{tabular}

a standard error of the mean

" estimated: $418 \mathrm{~kJ} \mathrm{ME} / \mathrm{kg} \mathrm{W}^{0.75} \mathrm{x}$ mean metabolic weight $\mathrm{x}$ duration

$\therefore$ wool included

TABLE 7

Protein deposition in lamb body

\begin{tabular}{|c|c|c|c|}
\hline & \multicolumn{2}{|c|}{ Group } & \multirow{2}{*}{$\mathrm{SE}^{\mathrm{a}}$} \\
\hline & $\mathrm{l}$ & $\mathrm{H}$ & \\
\hline Protein intake, g/day & 164 & 162 & 10 \\
\hline \multicolumn{4}{|l|}{ Protein deposition } \\
\hline in $E B W$ gain, g/day & 33.9 & 36.1 & 2.1 \\
\hline in wool gain, g/day & 2.9 & 3.0 & 0.2 \\
\hline total, g/day & 36.8 & 39.1 & 2.4 \\
\hline in $\%$ of protein intake & 22.4 & 24.0 & 1.1 \\
\hline
\end{tabular}

a standard error of the mean

and $39.1 \mathrm{~g} / \mathrm{d}$ of total gain, while the animals from group L retained 33.9, 2.9 and $36.8 \mathrm{~g} / \mathrm{d}$, respectively. Rams from group $\mathrm{H}$ retained $24.0 \%$ of dietary protein intake, whilc animals from group L, $22.4 \%$.

\section{DISCUSSION}

In the performed experiments, the influence of different levels of $\mathrm{ME}$ in complete pelleted dicts on performance as well as protein and encrgy deposition in the body of Black-headed Mutton sheep x Polish Merino crossbred rams was ascertained.

Lambs from both groups reached relatively high body weight gains, although rams fed diets containing $12.86 \mathrm{MJ} \mathrm{ME/kg} \mathrm{dry} \mathrm{matter} \mathrm{(group} \mathrm{H}$ ) were characterized by $9.6 \%$ higher growth rate and by $11 \%$ lower protein consumption per unit of 
body weight gain. Daily weight gains obtained in these experiments were higher than those in experiments carried out on Polish Merino rams reported by Urbaniak (1986, 1995), Urbaniak and Potkański (1987) and Żcbrowska et al. (1992), which were fattened to a similar final body weight, and on other Merino-type shecp (Veress et al., 1984; Fix et al., 1988; Ball et al., 1996; Manso et al., 1998). However, the growth ratc of rams from this experiment was lower than that of typical meattype lambs whose mean daily body weight gains, depending on experimental conditions, range from 267 to $414 \mathrm{~g}$ (Theriez et al., 1982a; Bovolenta et al., 1998; Tatum et al.. 1998). The obtained results indicate that crossbred lambs derived from the crossing of Black-headed Mutton sheep with Polish Merino ewes are characterized by high genetic predispositions with regard to growth rate and feed utilisation which exceed, in this regard, the Polish Merino breed. It is worth emphasizing that the genetic potential associated with the growth of these crossbreeds is utilized better when the animals are fed diets with higher encrgy concentrations.

In the case of meat-type lambs, the wool yicld is less important. Mean daily crude wool fibre production obtained in these investigations was not significantly correlated with the energy concentration in the diet. The obtained values of this parameter (3.66-3.75 g/d) differed from results obtained in experiments conducted on Mcrino-type lambs in which daily crude wool fibre production ranged from 3.80 to $5.10 \mathrm{~g}$ (Reis. 1969; Urbaniak, 1984, 1995). The use of dicts of different energy concentration in this experiment did not significantly affect slaughter percentage or carcass morphological composition. However, the concentration of protein was higher and fat was lower than in rams of the Polish Merino breed that were slaughtered at similar body weights in experiments carried out by Urbaniak (1986) and Pająk et al. (1992). The obtained values of these parameters correspond with results reported by ARC (1984) for meat-type lambs.

The chemical composition of EBW did not depend on the energy level in the feed. A high protein concentration in EBW of rams was recorded (18.59-18.82\%) and the chemical composition of EBW was more advantageous in comparison with Merino-type lambs in experiments conducted by Urbaniak (1986), Fix et al. (1988) and Pająk et al. (1992).

The assessment of utilisation of dietary ME on lamb growth using the comparative slaughter technique requires the determination of encrgy intake, encrgy content in animals' bodies at the beginning and end of an experiment, as well as maintenance requirements. The maintenance requirement was assumed, after Ørskov and McDonald (1970), Theriez el al. (1982b), and Urbaniak and Potkański (1987), at the level of $418 \mathrm{~kJ} \mathrm{~kg} \mathrm{~W} 6.75$.

Because rams from group $\mathrm{H}$ were characterized by a higher growth rate and shorter fattening period, the total ME intake during the entire period of the experiment was similar to the amount of energy intake by animals from group L. so the average maintenance requirements of animals from group $\mathrm{H}$, in relation to 
mean metabolic weight, were, therefore, lower. The above interdependencies are why the quantity of $\mathrm{ME}$ available for growth in lambs from both groups was similar and animals from group $\mathrm{H}$ achieved a slightly higher $(0.40)$, albeit statistically non-significant, value of the $\mathrm{k}_{\mathrm{f}}$ coefficient in comparison with animals from group $\mathrm{L}$ (0.38). In general, the obtained values of the $\mathrm{k}_{\mathrm{f}}$ cocfficient were higher than in the case of investigations carried out on Polish Merino lambs by Urbaniak (1986, 1995) and Pająk et al. (1992) and similar to rescarch results reported by Theriez et al. (1982b) and ARC (1984), which were carried out on meat-type lambs.

In the performed experiments a distinct, but statistically non-significant, increase in protein deposition in EBW of lambs fed diets with higher energy concentrations (group H) was observed, as confirmed by the correlations in the growth rate, production of clean wool fibre and feed conversion ratio. The amount of protein deposited in EBW gain was higher than in studies conduced by Urbaniak on Polish Merino sheep (1986, 1995).

Summing up the results of investigations discussed in this paper, it can be concluded that crossbred lambs of Black-headed Mutton sheep x Polish Merino are characterized by a higher growth rate and better feed conversion ratio and, simultancously, by lower production of clean wool fibre than lambs of Polish Merino breed. A higher meat content and lower fat content in carcass accompanicd by a better, from the consumer's point of view, chemical composition of EBW support the conclusion that the examined crossbred lambs fulfil the requirements of meat-type sheep and, consequently, can be recommended for further development of this direction of sheep production in Poland.

\section{REFERENCES}

Agricultural Research Council, 1984. Nutrient Requirements of Ruminant Livestock. Commonwealth Agricultural Burcaux, Slough

Ball A.J.. Thompson J.M., Pleasants A.B., 1996. Seasonal changes in body composition of growing Merino sheep. Livest. Prod. Sci. 46, 173-180

Bovolenta S.. Piasentier E., Peresson C., Malossini F.. 1998. The utilization of diets contanting increasing levels of dried brewers grains by growing lambs. Anim. Sci. 66, 689-695

Goering H.K., Van Soest P.J., 1970. Forage Fibre Analysis. USDA, ARS. Agric. Handbook, No. 379 Gut A., Slósarz P., 1995. Genesis and methods of formation and of selection in Polish Suffolk sheep -- the synthetic sire line. Rocz. Akad. Roln.. Poznan, CCI.XXII, 67-76

Fix H.P., Brutzke M., Peschke. I.. Hoffman M.. 1988. Studies on the nutrient and encrgy retention of growing lams 2. Result of slaughtering and body analyses. Arch. Anim. Nutr. (Berlin) 38 . 327-341

Manso T., Mantecon A.R.. Giraldez. F.J, Lavin P., Castro T., 1998. Animal performance and chemical body composition of lambs fed diets with different protein supplements. Small Ruminant Res. $29,185-192$ 
Orskov E.R., Mc Donald I., 1970. The utilization of dictary energy for maintenance and for fat and protein deposition in young growing sheep. Eur. Assoc. Anim. Prod. 13, 121-124

Pająk J., Zebrowska T., Zebrowska H., 1992. Protein content in the diet for fattening lamb.2. The chemical and amino acid composition of the body and utilization of amino acid apparently absorbed in the small intestine. J. Anim. Feed Sci. 1, 27-36

Reis P.J., 1969. The growth and composition of wool. V. Stimulation of wool growth by the abomasal administration of varying amounts of cascin. Aust. J. Biol. Sci. 22, 745-759

Steel R.G.D., Torrie J.H., 1960. Principles and Procedures of Statistic. McGraw - Hill, New York, pp. 106-110

Tatum J.D., Dewalt M.S., Levalley S.B.. Savell J.W. Williams F.L., 1998. Relationship of fecder lamb frame size to feedlot gain and carcass yield and quality grades. J. Anim. Sci. 76, 435-440

Theriez M. Villette Y., Castrillo C.. 1982a. Influence of metabolizable energy content of diet and of feeding level on lamb performance. 11. Utilization of metabolizable cnergy for growth and fattening. Livest. Prod. Sci. 9. 487-500

Theriez M., Villette Y., Castrillo C., 1982b. Influence of metabolizable energy content of the diet and of feeding level on lamb performances. Growth and body composition. Livest. Prod. Sci. 9 . $471-485$

Urbaniak M., 1986. Protein requirement of Merino lambs fattened from 20 to $40 \mathrm{~kg}$ liveweight. Rocz. Akad. Roln., Poznañ. Rozpr. Nauk., No 161

Urbaniak M., 1995. Effects of blood meal, fish meal, soybean meal or cascin on rumen protein metabolism in lambs. Small Ruminant Res. 18, 207-212

Urbaniak M., Potkański A., 1987. Tissue protein and energy deposition in lamb body fed isocaloric complete pelleted diets with different levels of nitrogen. Proceedings of $5^{\text {th }}$ International Symposium on Protein Metabolism and Nutrition. Rostock (Germany), pp. 106-108

Veress L., Vadane Kovacs M., Lovas L., Vagvolgyi O., Radnai L., Makay B., 1984. Examination on the meat production and meat quality of fast growing lambs. I. Hungarian Merinos. Állattennyés7tés $33.57-67$

Żebrowska T., Żebrowska H., Pająk J., 1992. Protein content in the diet of fattening lambs. I. Liveweight gain, efficiency of feed utilization and digestibility of nitrogen and amino acids in the smal! intestine. J. Anim. Feed Sci. 1, 15-25 


\section{STRESZCZENIE}

Produkcyjność oraz skład ciała jagniąt mieszańców czarnogłowej owcy mięsnej i merynosa polskiego żywionych mieszankami pelnoporcjowymi o różnej koncentracji energii

Trzydzieści dwa tryczki mieszańce czarnogłowej owcy mięsnej i merynosa polskiego o średniej początkowej masie ciała około $22 \mathrm{~kg}$, podzielono na dwie grupy i żywiono dwiema izobiałkowymi, pełnoporcjowymi, granulowanymi mieszankami o niskiej (grupa L) lub wysokiej (grupa H) koncentracji energii. Zwierzęta tuczono do końcowej masy ciała około $36 \mathrm{~kg}$.

Średnie dzienne przyrosty masy ciała jagniąt $\mathrm{z}$ grup L i H wynosiły odpowiednio 228 i $250 \mathrm{~g}$ ( $\mathrm{P} \leq 0.05$ ), a produkcja czystego włókna wełny 3,66 i 3,75 g/d. Zużycie energii metabolicznej (EM) na $1 \mathrm{~kg}$ przyrostu wynosiło 56,6 i 54,8 MJ, a białka ogólnego 718 i 649 g, odpowiednio w grupach L i H. Koncentracja EM w dawkach nie miała istotnego wpływu na wydajność rzeźną i skład morfologiczny tusz. Zawartość białka w $1 \mathrm{~kg}$ masy ciała netto $(\mathrm{MCN})$ wahała się od 18,6 do $18,8 \%$, tłuszczu od 17,6 do $18,1 \%$, a wartość energetyczna od 11,25 do $11,55 \mathrm{MJ}$, odpowiednio w grupach L i H. Wykorzystanie EM dostępnej dla wzrostu $\left(\mathrm{k}_{\mathrm{f}}\right)$ przez jagnięta $\mathrm{z}$ grup L i H było podobne $(0,38$ i 0,40$)$. Zwierzęta $\mathrm{z}$ grupy $\mathrm{H}$ odłożyły nieco więcej białka w przyroście MCN $(39,1 \mathrm{~g} / \mathrm{d})$ niż jagnięta z grupy L $(36,8 \mathrm{~g} / \mathrm{d})$. 